\title{
Sustainable tourism: its evolution and its future
}

\author{
Bernard Lane \\ Founding Editor of the Journal of Sustainable Tourism \\ EURAC Research, Centre for Advanced Studies
}

\begin{abstract}
This paper analyses the evolution of the concept of sustainable tourism from its beginnings as a reaction by European academics to uncontrolled tourism development in c. 1970-85, leading to basic sustainable tourism research in the late 1980s, followed by a more proactive and sophisticated second generation research phase post c. 2010. Twenty future research growth are discussed. The paper concludes that the future of sustainable tourism lies on it being implemented by businesses and policy makers. That relies on academics becoming more involved with business and policy work requiring the creation of multi-disciplinary institutes and international research teams. Examples are given.
\end{abstract}

Keywords: implementing sustainable tourism, research growth areas, multidisciplinary research institutes, international research teams.

JEL classification: Q01, Q20, Q30, Z32.

\section{Resumen}

Este trabajo analiza la evolución del concepto de turismo sostenible, desde sus inicios, como una reacción de los académicos europeos al desarrollo turístico incontrolado en el periodo 197085, que condujo a la investigación básica del turismo sostenible a finales de los años ochenta, seguido por una fase de investigación de segunda generación más proactiva y sofisticada alrededor del año 2010. Se discuten veinte tópicos de desarrollo de investigación futura. El documento concluye que el futuro del turismo sostenible radica en su implementación por parte de las empresas y los responsables políticos. Eso depende de que los académicos se involucren más con la industria y la política, lo que requiere la creación de institutos multidisciplinares y equipos de investigación internacionales. Se presentan algunos ejemplos.

Palabras clave: implementación de turismo sostenible, investigación de áreas de crecimiento, institutos interdisciplinares de investigación, equipos de investigación internacionales.

Clasificación JEL: Q01, Q20, Q30, Z32.

\section{The beginning: a reaction to growth}

Since the Second World War tourism has experienced remarkable growth, first in the western world, and more recently, worldwide. Most readers of this journal will be aware that from a low base of 25 million international tourism arrivals in 1950 , international numbers rose to 1235 million in 2016, with many more travellers forecast for future years (http://media.unwto.org/press-release/2017-07-14/strongtourism-results-first-part-2017; Dwyer, 2018). Growth took place in part because of developments in communications and transport and in part because of private sector investment, backed by strong public sector investment, often indirectly by 
providing infrastructure. But most fundamental to tourism's post war growth have been changes in developed world societies, with increasing disposable incomes, increasing levels of formal and informal education, and increasing awareness of the world's attractions. Perhaps most fundamental of all, tourism has become a fashion item: it is now fashionable to travel.

Tourism as an academic discipline began to grow in the 1960s, loosely in parallel to the growth in tourist numbers. Tourism research followed. In 1968, the first major tourism research journal, The Journal of Travel Research (JTR) was founded by its Editor, Charles R. Goeldner: he edited JTR for 35 years. Its opening paper, by Robert A. Peattie, a consultant, was, interestingly, on tourism advertising. JTR remains one of the Big 3 tourism research journals. It was joined by Annals of Tourism Research in 1973, and Tourism Management in 1980 (until 1982, Tourism Management was known as the International Journal of Tourism Management). There are now over 200 tourism research journals: tourism related research papers are also accepted by many other journals (McKercher, 2005; McKercher, Law and Lam, 2006). For most academics, the availability of peer reviewed research journals in which to publish is an essential requirement.

Increasing levels of tourism have, however, come at a heavy cost to host societies, cultures, and environments, with the processes and impacts well documented since the 1970s (Krippendorf, 1975, 1987; Briassoulis, 2013; Briassoulis and van der Straaten, 2013). And, just as changing levels of awareness and education in societies have encouraged tourism, so have they also encouraged aware and educated societies to question the costs of development and change brought about by tourism's growth. That questioning has not been confined to changes brought about by tourism. The consequences for people, nature and places of economic growth and change across the whole economy began to concern people many years ago, in the late 1960s and 1970s. Those years were exciting and stimulating times for radical thought generally: the war was over, we had enough to eat, and many of us sought to create a different and better world. The society wide questioning of economic growth, and the emergence of counter growth movements is typically dated back to the creation of the Club of Rome in 1968, "a group of world citizens, sharing a common concern for the future of humanity" (see www.clubofrome.org). Its publication of Limits to Growth came in 1972 (Meadows, Meadows, Randers and Behrens, 1972). This controversial book has sold over 16 million copies, and been revised and republished many times. The Club's foundation was contemporaneous with Friends of the Earth (1969), and Greenpeace (1972) - although both of the latter were originally anti-nuclear as much as pro-environmental organizations. The publication of Limits to Growth began a movement which led towards the concept of Sustainable Development, a concept first given international recognition by the Brundtland Report (WCED, 1987). 


\section{The rise of sustainable tourism and sustainable tourism research}

The development of the concept of sustainable tourism can be traced back to the 1970s. The impacts of unregulated and irresponsible tourism growth in the European Alps, and around the Mediterranean Sea, provoked much concern, mainly amongst academic and other thinkers and commentators in central Europe, Italy and France. In 1975 Jost Krippendorf published Die Landschaftsfresser (The Landscape Eaters), describing the impacts of tourism on the Alpine landscape. His 1984 book Die Ferienmenschen took the discussion much further. In 1987 the book was translated into English as The Holiday Makers: understanding the impact of leisure and travel. It sought not regulation but a change in life style and behaviour from all parties involved. It sought a new form of tourism, that would use more informed and responsible marketing; a holistic and balanced approach to development and better trained tourism personnel of all kinds; host populations prepared to manage tourism; better informed holidaymakers and research into the drivers and issues that could lead to a more sustainable tourism.

Jost Krippendorf was just one of many European academics discussing the need for a new approach to tourism, and meeting in Germany, Italy, Austria and France in the 1980s. In 1985, 1986 and 1987 tourism was the subject of the now famous Toblacher Gesprächer, European think tanks on subjects of social and environmental concern. One outcome was a pioneering book -in German- on the new tourism (Krippendorf, Zimmer and Glauber, 1988). Toblach is a small town located in the South Tyrol or Alto Adige region of Italy, with a famous nineteenth century Grand Hotel, now a cultural and conference centre. The Toblacher Gespräche were founded in 1985 by Hans Glauber (1933-2008), a leading ecologist, sociologist and artist, to explore environmental, social and economic futures. They continue to this day: in 2017 discussions concerned the Sharing Economy, Digitalization and Sustainable Development.

These early discussions were valuable, but were largely based on opinions, and ideologies. There was little hard research into how sustainable tourism could be devised, applied and assessed. Jost Krippendorf (1938-2003) realised the problems facing the implementation of the concept, and described them in an interview held in 1992:

"(with tourism development) there is always the pressure of short term economic interest, especially from the construction industry, the building industry, because a lot of people earn their living from building second homes or building infrastructure. If we tell them now to stop or to slow down they will say that we will lose jobs. Employment is always put forward to explain that growth is still necessary.

I think the special issue is that we really have to come to action, and to measurable action, in the field of sustainable tourism. We have to develop -and the researchers should work together on this with the industry and with the 
state- a really practical and simple way of measuring sustainability. Not very complicated carrying capacities, targets etc., but some five or six indicators with which those responsible for the business itself, in the local communities, in the regions and even on the national scale, could then measure every year what progress has been made in the fields of lower energy consumption, of the surface (area) used for tourism infrastructure, of $\mathrm{CO}_{2}$ emissions or whatever other indicators could be taken. We have spoken a lot about sustainable tourism and tried to define it but we haven't achieved very much and if we want to show what has been achieved then we should be able to measure it, not only to talk about it. And so this eco-balance, or eco-control systems, should be developed very rapidly now by all those who really want to have progress in this field. I hope everyone who has spoken about sustainability in the last decade really wants to do something about it. So let us develop these indicators and measure them every year, and publish the results of the measurements every year so that every one in the wider public can then pin all those people on the wall and say 'you said that you have sustainable tourism and now we see that that is not the case... If we really don't try the first step nothing will change, but perhaps if we make the first step, then, everything will change" (Krippendorf and Lane, 1993, pp. 55-57).

The case for a dedicated research journal to help encourage peer reviewed research was, therefore, made, confirming the decision which had been tentatively made by the forerunners of Channel View Publications to launch the Journal of Sustainable Tourism (JOST) in 1993. JOST was not -and is not- the only tourism research journal to publish papers on sustainable tourism. Both Annals and Tourism Management, amongst Social Science Citation Index journals, have published many, as have other journals. But it was one of the first niche market specialised tourism journals. It defined sustainable tourism as:

"a positive approach intended to reduce the tensions and friction created by the complex interactions between the tourism industry, visitors, the environment and the communities which are host to holidaymakers. It is an approach which involves working for the long-term viability and quality of both natural and human resources. It is not antigrowth, but it acknowledges that there are limits to growth. Those limits will vary considerably from place to place, and according to management practices. It recognises that for many areas tourism was, is and will be an important form of development. It seeks to ensure that tourism developments are sustainable in the long term and wherever possible help in turn to sustain the areas in which they operate. And, for good measure, sustainable tourism also aims to increase visitor satisfaction. This last point is not an idle one. Satisfied visitors are usually also visitors who become concerned and caring for the places they visit. They often provide long-term and repeat business" (Bramwell and Lane, 1993, p. 2). 
Since 1993, sustainable tourism has become more complex, tested and refined, and numerous definitions have been written, but its essence remains the same. It seeks to make the interaction between tourism and the world -natural, man-made and cultural- a better experience for all concerned.

From its beginnings, sustainable tourism was a concept created and developed very largely by academics. There have been many attempts to involve the tourism "industry" in discussions and implementation and many attempts to involve public sector policymakers too. There have also been attempts to interest the market -the tourists themselves- in sustainable tourism, largely through occasional discussions in the media. But few have yielded major results.

Sustainable tourism was, therefore, created by academics, and academics have been enthusiastic discussants and researchers, but they have not-so far-succeeded in driving the implementation of sustainable tourism. But there has been progress. Much of the progress made in sustainable tourism industry reflects issues in the realpolitik of the growing tourism industry.

\section{Sustainable tourism research $1990-2010$}

Sustainable tourism has always been a contested debate: it raises practical as well as ideological issues and is therefore inevitably contestable (McCool,Butler, Buckley, Weaver and Wheeller, 2013). Perhaps, most importantly, the tourism business is a very conservative growth area: there can be serious financial and reputational risks if innovations go wrong. Business as usual is a typical watch word (see Dwyer, 2018). But sustainable tourism research has made progress, with several thousand research papers submitted over the last 30 years, and approximately 2,000 published.

Sustainable tourism began as a purely reactive concept, trying to reduce or stop tourism's and tourist's negative impacts. Early outlines simply listed the negative impacts down the left side of the page and then had a wish list of their opposites, presumed to be positive outcomes, down the right side of the page. Only gradually has sustainable tourism become pro-active, trying to create positive change (Lane, 2009). To this day some commentators and researchers appear to enjoy criticising tourism. Academics are, after all, trained to analyse and criticise The key to achieving sustainable tourism, is however to go further: to carry out analytical review and criticism, to devise and then implement product innovation and effective tourism management techniques, and then carry on a rolling review, evaluation, criticism and improved management process.

Progress in sustainable tourism research concentrated in the early years on:

- Discussions and definitions, and devising basic assessment / evaluation programmes for small scale sites.

- Assessment of resident's perceptions of and attitudes to tourism development. Nunkoo, Smith and Ramkissoon (2013) carried out a review of no less than 140 
papers on this subject published between 1984 and 2010: since 2010 even more have been published.

- Research into community based tourism, and community empowerment. Community tourism was seen as a possible sustainable alternative to company based developments based outside the host area. Examples include (Jamal and Getz, 1995; Okazaki, 2008). Salazar (2012) presents alternative views in this often difficult area.

- Testing a range of management techniques, including visitor management programmes (e.g. Dowling, 1993) especially those for protected areas, more sustainable accommodation provision (with an emphasis on hotel management e.g. Chan, 2005; Kasim, 2009) ), transport centred research (Lumsdon, 2000) and the creation of partnership programmes (McCool, 2009).

- Local and individual projects, some innovative, many very short term (e.g. Hobson and Mak, 1995; Barke and Newton, 1995).

- Local sustainable tourism strategies, usually written by or for local governments (e.g. Human, 1994; Wray, 2011).

- Certification programmes of varying types and varying quality, largely voluntary membership programmes with the inherent problems that membership programmes have: such programmes, urged in Krippendorf's interview above, are often essentially prisoners of their members, succeeding with the success of their members, failing if their members dilute their aims or leave the programmes (Hawkins, 1995; Medina, 2005; Zielinski and Botero, 2015).

- Discussion and trialling of indicators designed to show progress (or lack of progress) in implementing sustainable tourism (e.g. Crotts and Holland, 1993). Indicators have, on balance, proven difficult to devise and use.

- Discussion of the ethics and key concepts of the "subject" -one of the most important examples of this has been work by authors such as Farrell and Twining Ward (2005), Shultis and Way (2006) and McKercher and Chen (2014)-, which introduced fashion trends, uncertainty, risk, chaos and organic change into the previously linear, inevitable progression development scenario.

- Research and case study work: a wealth of knowledge now exists on some issues. We understand, for example, more about the role of information provision and interpretation in implementing sustainable tourism (Bramwell and Lane, 1993; Tubb, 2003).

Gradually, however, sustainable tourism took on wider roles, and became a concept with global not just western relevance. And sustainable tourism has begun to become more than simply an environmentally friendly form of tourism. It has become the conscience of a previously conscience free activity, a route towards innovation in product development, marketing and accommodation creation, and a source of new types of destination planning. Sustainable tourism, and sustainable tourism research, became innovative and pro-active (Bramwell and Lane, 2012). 
A series of new research areas has emerged in the last c. ten years, which might be named "second generation". They were typically areas that the founding fathers of the subject had not thought about or expected to emerge. They were often much more difficult and demanding research areas, and usually required a holistic and multi-disciplinary approach. Paradoxically, they may either drastically change sustainable tourism research or render it unsustainable. The list below gives an indication of some of the likely growth areas, reflecting recent developments and outstanding knowledge gaps. It is not exhaustive. It is based on the author's 25 years of editing the Journal of Sustainable Tourism, and over 30 years working as trainer, animateur and consultant with communities, policy makers, NGOs, and tourism based companies of many kinds.

\section{Second generation sustainable tourism research 2011 onwards: twenty likely future growth areas?}

1) Partnership creation and management for sustainable tourism was highlighted by the Journal of Sustainable Tourism's 1999 Special Issue on this area, Volume 7, Issues 3 and 4 (Bramwell and Lane, 1999, 2000). Almost all tourism activities require forms of partnerships to bring together the numerous and fragmented stakeholders involved: marketing, information, product development, accommodation, hospitality, catering and transportation elements that together make tourism work. But most destinations rely on loose, ad hoc partnerships which do not focus on sustainability. Stanford and Guiver (2016), provide a useful example of a successful sustainable transport partnership within a protected area: Scuttari, Volgger and Pechlaner (2016) also offer much food for thought, but there is a need for more and deeper analysis of how partnerships work and could work better to create more sustainable results.

2) Governance issues emerged as a key area in the implementation of sustainable tourism in Bramwell (2011) and Bramwell and Lane (2011), and in the collection of papers published alongside those papers in the JOST Special Issue, in Volume 19 (4 and 5) published in 2011. Tourism is remarkably ungoverned and perhaps in some respects ungovernable, in part because of the fragmented ownership of its private sector elements, and in part because of the changing and complex nature of the public sector components that both control infrastructure and have some governance powers through planning permissions and some marketing activities. The international aspects of tourism also make its governance difficult. Much more multi-disciplinary work is needed on tourism governance at all levels. Dredge and Whitford ( 2011) provide food for thought.

Tourism is also a relatively leaderless industry, except in terms of lobbying. Leadership for sustainable tourism is important at local, regional, national and international levels. Research on that issue is rare, but McGehee, Knollenberg and Komorowski (2015) have made a useful start. 
3) Protected areas as governance prototypes. Protected Areas, including National Parks, have had an interesting relationship with tourism. Created to protect natural areas, in the past they had a negative approach to tourism, and little understanding of how sustainable tourism could be a valuable conservation tool (Sharpley and Pearce, 2007). But the relationship between protected areas and sustainable tourism is fast changing for the better: see Eagles (2002) and (2014); Job, Becken and Lane (2017). Getzner, Lange Vik, Brendehaug and Lane (2014) explore the possibilities for using protected areas, with their legal powers and political power as potential prototypes for sustainable tourism governance models. Slocum (2017) is of interest in this context.

4) Destination management is a complex issue which is connected to governance, and could potentially play an essential role in sustainable tourism implementation. Destination are changing from centralized resorts of the sun/sea/ sand tourism era towards decentralized, niche market destinations, with balanced multi-activity economies, and now include major cities of many types (see Lane and Kastenholz, 2015; Anton Clavé and Wilson, 2017). There is an urgent need for more and deeper research into the mechanics, politics and outcomes of sustainable destination management.

5) Visitor experience planning was developed by the US National Park Service in the late 1990s. It should be part of destination management planning, and destination staff training but rarely is. Academic researchers appear to be shy of it, perhaps because they see it as a job for consultants, and that appears to frighten many academics -see later in this paper. Two interesting examples may be useful: https://www.nps.gov/hfc/pdf/ip/interp-visitor-exper.pdf and http://www. visitblaenavon.co.uk/en/Publications/WorldHeritageSite/LookingAfterBlaenavon/ VisitorExperienceandInterpretationPlan2007.pdf.

6) Financial and taxation instruments are commonly used outside tourism to regulate and control markets, and market suppliers. Tourism has fought shy of this form of control - the anger created by the "tourism tax" imposed by the government of the Balearic Islands in 2002 and 2016 is worth noting, and is summarised at https:// www.spain-holiday.com/rentalbuzz/the-new-balearics-eco-tourism-tax-explained. But it seems likely that as neo-liberalism increases, financial and taxation issues will assume greater importance. Eagles (2002) first discussed this subject in the context of sustainable tourism, and a range of ideas have been put forward by Whitelaw, King and Tolkach (2014) and by Dinica (2017).

7) Climate change issues were first discussed in relation to sustainable tourism in 1994 (Wall and Badke, 1994). The Journal of Sustainable Tourism has published Special Issues on this subject in 2006 and 2010, plus contrasting Opinion Pieces on the relationship between sustainable tourism and climate change in 2011 (Weaver, 
2011 and Scott, 2011). Climate Change and its links to sustainable tourism have continued to attract research and disagreement, and are likely to do that for many years to come. But basic research papers on climate change have been joined by growing research on perhaps the most fundamental subject for sustainable tourism's future - how to bring about behavioural change amongst tourists and across tourism businesses and managers in order to reduce tourism's contribution to climate change.

8) Behavioural change has emerged as a growth area for sustainable tourism research since the publication of Cohen, Higham and Cavaliere's research exploring binge flying (2011). There have been numerous recent papers: Higham, Cohen, Peeters and Gössling (2013) is an important example. It moves the discussion towards the psychology of tourism, and of change - bringing close comparisons to the psychologies of health and ways of life. Interestingly, the founding fathers of sustainable tourism, while discussing behavioural change did not use those words or link it to the study of psychology and addictions. Bramwell and Lane (2013) set it in context.

9) Scenario planning and futures research was also rarely discussed in the early days, but has become increasingly important for both business and public sector policy purposes. The Journal of Sustainable Tourism published a special issue on this area in 2012 (see Gössling and Scott, 2012) A number of recent papers have looked to the future, but have not yet linked tourism to the wider futures thinkers and researchers (see for example Landry and Bianchini, 1995; Lanier, 2017; Thaler and Sunstein, 2008; Sunstein, 2017). This is an area in need of more multi-disciplinary work.

10) Transformational tourism was much discussed by early sustainable tourism scholars, who dreamt of a tourism which would inspire, uplift and educate travellers, rather than simply offer them holidays. The concept of transformational tourism was then forgotten as adventure, cultural and heritage tourism came to the fore, and also as volunteer tourism claimed to be transformational for many young people. Recently the subject has returned, as both physical and mental health issues have become strong on national spending agendas, and as the idea of tourism being part of the experience economy has been recognised (see Wolf, Ainsworth and Crowley, 2017; Pine and Gilmore, 1999).

11) Slow Tourism's concepts, or some of them, were also discussed in the 1980 s, but never named as such. It has returned to the sustainable tourism discourse in recent years, linked to climate change, emissions reductions and behavioural change. It seeks to provide/give access to alternative travel modes - avoiding aviation in particular. Slow Tourism's agenda and issues are discussed by Dickinson and Lumsdon (2010) and by Fullagar, Markwell and Wilson, (2012). So far slow tourism has not been tested on the ground to any extent, nor have its ideas been used 
fully in a destination management programme, although there is active interest in doing so (Lane, 2016).

12) City tourism, often known as Urban Tourism, has grown rapidly in the last 50 years, as cultural and heritage tourism has competed successfully with traditional resorts. It was confined to capital cities, and to a few iconic historic cities, but is now much more widespread. Tourism is used as a regeneration tool for industrial cities, as a diversification tool, as a way of attracting start-ups by life style entrepreneurs. Small cities have become alternative weekend breaks, often assisted by the rise of low cost airlines and by the growth of low /medium cost national and international hotel chains such as the Accor Group, or the Best Western franchise. Eco-cities have emerged, with Melbourne, Australia, leading that group. New Museum and Gallery construction has been important, along with growth in niche market festivals, and events.

City based tourism has, however, taken sustainable tourism academics by surprise: many of sustainable tourism's key concepts and management techniques refer to rural / natural areas. Cities were thought to be big enough and robust enough not to need special management measures. But the tourism's ongoing growth, and new developments such as Airbnb, drinking and drug taking, has raised the need for a Sustainable Tourism Charter especially designed for Cities. Key papers in this area include Miller, Merrilees and Coghlan (2015), Maxim (2016), Anton Clavé and Wilson (2017).

13) Markets and marketing. In 1968, the Journal of Travel Research's first paper covered tourism marketing. The pioneers of sustainable tourism longed for responsible marketing. But for many academics involved with sustainable tourism, marketing was almost a taboo subject. The flow of papers to JOST about marketing tended to be concerned with working out who and how many people were interested in the environment, and the size of the sustainable tourism market, led by Sara Dolnicar, whose first of many papers dates back to 2004 (although Eagles, 1995, was a very early researcher in this area). Marketing, despite its links to behavioural change, remained little covered unto 2017's JOST Special Issue (Volume 25). Font and McCabe (2017) point out the many areas that need research attention.

14) Data development and handling. Many of Dolnicar's papers have pointed out the need to assemble and analyse data about tourist's intentions, their drivers and the realities of tourist's actions for many years now, with Babakhani, Ritchie and Dolnicar (2017) recently testing radical new data collection methods, and pointing out social bias problems in many earlier market assessment papers. Smart Tourism, with its links to Big Data and other new approaches, is also a relevant growth area (Gretzel, Sigala, Xiang and Koo, 2015). 
15) Social media is well known to be a new, fast growing area of enormous importance to many economic activities. Detailed work on its links and value to sustainable tourism remains to be done: see, however, Gössling (2017) and Sigala and Gretzel (2017).

16) The roles of print and broadcast media. While IT and social media are key areas for further research, print and broadcast media remain very important in sustainable tourism's dissemination. McWha, Frost and Laing (2017) have published pioneering work on travel writing, but there remains research to do on newspapers, radio and TV travel programmes, their editors and writers and their potential links to behavioural change in particular and sustainable tourism in general.

17) De-growth is an idea that is close to the ideas of many advocates of sustainable development as a way to ease the pressure on the world's resources. It is a political, economic, and social movement which offers a response to the limitsto-growth dilemma. It is backed by the Washington DC based Worldwatch Institute (http://www.worldwatch.org/).

Hall (2009) provides an overview of de-growth in tourism, and of a kindred concept, steady-state tourism. Beeton and Benfield (2002) look at the role of demarketing as a regional route to tourism de-growth. Canavan (2014) examines degrowth as a regional tourism strategy in the Isle of Man. Research on degrowth may grow in the future. In 2017, the Journal of Sustainable Tourism issued a call for papers on degrowth in tourism: http://explore.tandfonline.com/cfp/pgas/rsus-sidegrowth-4q2017.

18) Social enterprises rather than community enterprises? Community enterprises were the great white hope of many early believers in sustainable tourism. Many problems have been found in practice -see Koutsouris (2009), Salazar (2012), Idziak, Majewski and Zmyślony (2015). But a range of new small enterprise opportunities are growing, of which social enterprise appears especially worthy of researching (see von der Weppen and Cochrane, 2012).

19) Indigenous tourism provides a special and severe test for many of sustainable tourism's management techniques. While very much a niche tourism market, in 2016, the Journal of Sustainable Tourism published a Special Issue on Sustainable Tourism and Indigenous people. Within a year, its opening paper (Carr, Ruhanen and Whitford, 2016) had been downloaded 8,000 times, and been cited 12 times - a remarkable performance. Clearly there is great interest in research linking sustainable tourism to the future of indigenous peoples.

20) Understanding business and businesses. This last subject is probably the most important on the list. While academics may have created and researched the concept of sustainable tourism, they have not-so far- been effective at implementing 
sustainable tourism. In part that is because businesses have been very wary of the concept: well illustrated in Font, Elgammal and Lamond (2017) in their paper on greenhushing. However, while businesses have been wary of sustainable tourism, sustainable tourism academics have been wary of businesses. The profit motive worries some academics; the idea of consultancy, of working for a client, worries others. And some are aware that reviewers and editors of tourism journals tend to prefer to see "pure" research rather than consultancy results (see Lane, 2018).

Higuchi and Yamanaka (2017) published a landmark paper on how academics can work with tourism businesses. They viewed consultancy as a form of knowledge sharing between researchers and businesses and stressed the need for long termism, embeddedness, trust and co-creation. In 2017, a pioneering book on how tourism businesses grow and think was published based on the Canary Islands (Aguiar Quintana and Batista Canino, 2017). While the book was written to inform tourism undergraduates, it offers researchers some valuable insights.

\section{But what about the future?}

This may seem like a strange question to ask, after a long list of important issues that need to be researched has been given. The real future of sustainable tourism, however, lies in it being implemented. Without success in implementation this good idea will lapse into irrelevance, especially as the world is becoming more neo-liberal in its ideologies.

But within that threat, however, there are the seeds of success. For business, involvement with academics can bring many dividends: better public relations, new marketing possibilities, new and productive partnerships, positive links to protected areas and pressure groups, access to innovative product development ideas, access to constructive business criticism, access to better market knowledge and potentially better trained graduate employees. Better public sector involvement with academics would also offer dividends in political and innovation terms.

For academics, the benefits could be equally rich. They too would benefit from the oxygen of publicity. They would be seen as increasingly relevant to society, nature, heritage and the economy. Research funding should be more accessible. Beyond the research world, close working with the industry could improve undergraduate and postgraduate teaching, and help graduates' job prospects. Critically, it could help develop a market for post experience courses, as part of a life-long learning programme for the industry and for the public sector: critical because, with declining birth rates, universities could run out of young people to teach, while not refreshing the knowledge and ideas base of the growing number of those who, in the future, could be in employment until at least their $70^{\text {th }}$ year.

This new alignment will not be easy. Lane (2018) notes five challenges to academics who wish to help move sustainable tourism from concept to an implemented model. Of those five, two are especially important. 
The first of is the need for multi-disciplinary research teams to be created that understand each other, that work together not in short term engagements but for the long term. The multidisciplinary Institute of Tourism and Sustainable Economic Development (TIDES) at the University of Las Palmas in the Canary Islands was created in 2010, bringing together 45 researchers from nine different departments (see www.http://tides.ulpgc.es/). In Australia, the Griffith Institute of Tourism at Griffith University, was created in 2014, bringing over 30 staff members together (see https:// www2.griffith.edu.au/institute-tourism). Sustainable tourism is one of its specialities.

The second challenge is to create international research teams to work together, an idea more easily developed in the age of the internet, Skype and low cost air travel than ever before. Only this type of venture can cope with the complexities of different geographies, cultures and political systems, and tourism is a very international system. The model to study here is that of Alter-Net, formed by applied biologists in 2009, which enables institutions from 18 countries to share the goal of integrating their research capability in order to: assess changes in biodiversity, analyse the effect of those changes on ecosystem services and inform the public and policy makers about this at a European scale (see http://www.alter-net.info/aboutalter-net, and Lane 2018).

Sustainable tourism has been criticised as a utopian dream (McCool, Butler, Buckley, Weaver and Wheeller, 2013). So has democracy. But Winston Churchill (1874-1965) is reputed to have said that democracy must survive because the alternatives are so much worse. The same could be said of sustainable tourism. Two other quotations from Churchill round off this paper:

"The first quality that is needed is audacity" - the people who created the sustainable tourism concept so many years ago had enormous audacity - and skills.

"I am an optimist: it does not seem to be much use being anything else".

\section{References}

[1] AGUIAR QUINTANA, T. and BATISTA CANINO, R. M. (2017). Successful Case Stsudies in the Canary Islands' Tourism Industry, Newcastle upon Tyne, Cambridge Scholars Publishing.

[2] ANTON CLAVÉ, S. and WILSON, J. (2017). «The evolution of coastal tourism destinations: a path plasticity perspective on tourism urbanisation». Journal of Sustainable Tourism, 25 (1), 96-112.

[3] BABAKHANI, N.; RITCHIE, B. W. and DOLNICAR, S. (2017). «Improving carbon offsetting appeals in online airplane ticket purchasing: testing new messages, and using new test methods». Journal of Sustainable Tourism, 25 (7), 955-969.

[4] BARKE, M. and NEWTON, M. (1995). «Promoting sustainable tourism in an urban context: Recent developments in Malaga city, Andalusia». Journal of Sustainable Tourism, 3 (3), 115-134. 
[5] BEETON, S. and BENFIELD, R. (2002). «Demand Control: The Case for Demarketing as a Visitor and Environmental Management Tool». Journal of Sustainable Tourism, 10 (6), 497-513.

[6] BRAMWELL, B. and LANE, B. (1993). «Sustainable Tourism: An Evolving Global Approach». Journal of Sustainable Tourism, 1 (1), 1-5.

[7] BRAMWELL, B. and LANE, B. (1993). «Interpretation and Sustainable Tourism: The Potential and the Pitfalls». Journal of Sustainable Tourism, 1 (2), 71-80.

[8] BRAMWELL, B. and LANE, B. (1999). «Editorial, Collaboration and Partnerships for Sustainable Tourism». Journal of Sustainable Tourism, 7 (3-4), 179-181.

[9] BRAMWELL, B. and LANE, B (Eds.) (2000). Tourism Partnerships and Collaboration: Politics, Practice and Sustainability. Clevedon, Channel View Publications.

[10] BRAMWELL, B. (2011). «Governance, the state and sustainable tourism: A political economy approach». Journal of Sustainable Tourism, 19 (4-5), 459-477.

[11] BRAMWELL, B. and LANE, B. (2011). «Critical research on the governance of tourism and sustainability». Journal of Sustainable Tourism, 19 (4-5), 411-421.

[12] BRAMWELL, B. and LANE, B. (2012). «Towards innovation in sustainable tourism research?». Journal of Sustainable Tourism, 20 (1), 1-7.

[13] BRAMWELL, B. and LANE, B. (2013). «Getting from here to there: Systems change, behavioural change and sustainable tourism». Journal of Sustainable Tourism, 21 (1), $1-4$.

[14] BRIASSOULIS, H. (2013). «Environmental impacts of tourism: A framework for analysis and evaluation». In H. Briassoulis and J. Van der Straaten (Eds.), Tourism and the environment: Regional, economic, cultural and policy (Vol. 6). New York, NY: Springer Science \& Business Media.

[15] BRIASSOULIS, H. and VAN DER STRAATEN, J. (Eds.) (2013). Tourism and the environment: Regional, economic, cultural and policy (Vol. 6). New York, NY: Springer Science \& Business Media.

[16] CANAVAN, B. (2014). «Sustainable tourism: development, decline and de-growth. Management issues from the Isle of Man». Journal of Sustainable Tourism, 22 (1), 127-147.

[17] CARR, A.; RUHANEN, L. and WHITFORD, M. (2016). «Indigenous peoples and tourism: the challenges and opportunities for sustainable tourism». Journal of Sustainable Tourism, 24 (8-9), 1067-1079.

[18] CHAN, W. W. (2005). «Predicting and saving the consumption of electricity in subtropical hotels». International Journal of Contemporary Hospitality Management, 17 (3): 228-237.

[19] COHEN, S. A.; HIGHAM, J. E. S. and CAVALIERE, C. T. (2011). «Binge flying: Behavioural addiction and climate change». Annals of Tourism Research, 38 (3): 10701089.

[20] CROTTS, J. C. and HOLLAND, S. M. (1993). «Objective Indicators of the Impact of Rural Tourism Development in the State of Florida». Journal of Sustainable Tourism, 1 (2), 112-120.

[21] DICKINSON, J. E. and LUMSDON, L. M. (2010). Slow travel and tourism. London: Earthscan.

[22] DINICA, V. (2017). «Tourism concessions in National Parks: neo-liberal governance experiments for a Conservation Economy in New Zealand». Journal of Sustainable Tourism, 25 (12), 1811-1829. 
[23] DOLNICAR, S. (2004). «Insights into Sustainable Tourists in Austria: A Data based A Priori Segmentation Approach». Journal of Sustainable Tourism, 12 (3), 209-218.

[24] DOWLING, R. (1993). «An Environmentally-based Planning Model for Regional Tourism Development». Journal of Sustainable Tourism, 1 (1), 17-37.

[25] DREDGE, D. and WHITFORD, M. (2011). «Event tourism governance and the public sphere». Journal of Sustainable Tourism, 19 (4-5), 479-499.

[26] DWYER, L. (2018). «Saluting while the ship sinks: the necessity for tourism paradigm change». Journal of Sustainable Tourism. DOI: 10.1080/09669582.2017.1308372.

[27] EAGLES, P. F. J. (1995). «Understanding the market for sustainable tourism». In S. F. McCool and A. E. Watson (Eds.), Linking Tourism, the Environment and Sustainability (pp. 25-33), 23-33. Ogden, UT: USDA (General Technical Report INT-GTR-323).

[28] EAGLES, P. F. J. (2002). «Trends in Park Tourism: Economics, Finance and Management». Journal of Sustainable Tourism, 10 (2), 132-153.

[29] EAGLES, P. F. J. (2014). «Research priorities in park tourism». Journal of Sustainable Tourism, 22 (4), 528-549.

[30] FARRELL, B. and TWINING-WARD, L. (2005). «Seven Steps Towards Sustainability: Tourism in the Context of New Knowledge». Journal of Sustainable Tourism, 13 (2), 109-122.

[31] FLINT, J. and RACO, M. (2012). The future of sustainable cities: Critical reflections. Bristol: Policy Press.

[32] FONT, X.; ELGAMMAL, I. and LAMOND, I. (2017). «Greenhushing: the deliberate under communicating of sustainability practices by tourism businesses». Journal of Sustainable Tourism, 25 (7), 1007-1023.

[33] FONT, X. and McCABE, S. (2017). «Sustainability and marketing in tourism: its contexts, paradoxes, approaches, challenges and potential». Journal of Sustainable Tourism, 25 (7), 869-883.

[34] FULLAGAR, S.; MARKWELL,K.and WILSON,E.(2012). Slow Tourism:Experiences and Mobilities, Bristol, Channel View Publications.

[35] GETZNER, M.; LANGE VIK, M.; BRENDEHAUG, E. and LANE, B. (2014). «Governance and Management Strategies in National Parks: Implications for Sustainable Regional Development». International Journal of Sustainable Society, 6 (1\&2). 82-101.

[36] GÖSSLING, S. (2017). «Tourism, information technologies and sustainability: an exploratory review». Journal of Sustainable Tourism, 25 (7), 1024-1041.

[37] GÖSSLING, S. and SCOTT, D. (2012). «Scenario planning for sustainable tourism: an introduction». Journal of Sustainable Tourism, 20 (6), 773-778.

[38] GRETZEL, U.; SIGALA, M.; XIANG, Z. and KOO, C. (2015). «Smart tourism: foundations and developments». Electronic Markets, 25 (3), 179-188.

[39] HALL, C. M. (2009). «Degrowing Tourism: Décroissance, Sustainable Consumption and Steady-State Tourism». Anatolia, 20 (1), 46-61.

[40] HAWKINS, R. (1995). «The green globe programme: Developing a greener future for travel and tourism». Journal of Sustainable Tourism, 3 (1), 59-60.

[41] HEELEY, J. (2011). Inside City Tourism: A European Perspective, Bristol, Channel View Publications.

[42] HIGHAM, J.; COHEN, S. A.; PEETERS, P. and GÖSSLING, S. (2013). «Psychological and behavioural approaches to understanding and governing sustainable mobility». Journal of Sustainable Tourism, 21 (7), 949-967. 
[43] HIGUCHI, Y. and YAMANAKA, Y. (2017). «Knowledge sharing between academic researchers and tourism practitioners: a Japanese study of the practical value of embeddedness, trust and co-creation». Journal of Sustainable Tourism, 25 (10), 14561473.

[44] HOBSON, J. S. P. and MAK, B. (1995). «Home visit and community-based tourism: Hong Kong's family insight tour». Journal of Sustainable Tourism, 3 (4), 179-190.

[45] HUMAN, B. (1994). «Visitor management in the public planning policy context: A case study of Cambridge». Journal of Sustainable Tourism, 2 (4), 221-223.

[46] IDZIAK, W.; MAJEWSKI, J. and ZMYŚLONY, P. (2015). «Community participation in sustainable rural tourism experience creation: a long-term appraisal and lessons from a thematic villages project in Poland». Journal of Sustainable Tourism, 23 (8-9), 13411362.

[47] JAMAL, T. B. and GETZ, D. (1995). «Collaboration theory and community tourism planning». Annals of Tourism Research, 22 (1), 186-204.

[48] JOB, H.; BECKEN, S. and LANE, B. (2017). «Protected Areas in a neoliberal world and the role of tourism in supporting conservation and sustainable development: an assessment of strategic planning, zoning, impact monitoring and tourism management at natural World Heritage Sites». Journal of Sustainable Tourism, 25 (12), 1697-1718.

[49] KASIM, A. (2009). «Managerial attitudes towards environmental management among small and medium hotels in Kuala Lumpur». Journal of Sustainable Tourism, 17 (6), 709-725.

[50] KOUTSOURIS, A. (2009). «Social learning and sustainable tourism development; local quality conventions in tourism: a Greek case study». Journal of Sustainable Tourism, 17 (5), 567-581.

[51] KRIPPENDORF, J. (1975). Die Landschaftsfresser: Tourismus und Erholungslandschaft, Verderben oder Segen? [The Landscape Eater: Tourism and Recreational Landscapes. Destruction or Blessing]. Bern, Hallwag Verlag.

[52] KRIPPENDORF, J. (1987). The Holiday Makers: understanding the impact of leisure and travel. London, Heinemann.

[53] KRIPPENDORF , J. and LANE, B. (1993). «Interview: Jost Krippendorf». Journal of Sustainable Tourism, 1, 1, 55-60.

[54] KRIPPENDORF, J.; ZIMMER, P. and GLAUBER, H. (1988). Für einen andern Tourismus (Towards an Alternative Tourism) Frankfurt am Main, Fischer Taschenbuch Verlag.

[55] LANDRY, C. and BIANCHINI, F. (1995). The Creative City, London, Demos, available at: https://www.demos.co.uk/files/thecreativecity.pdf.

[56] LANE, B. (2009). «30 years of sustainable tourism: Drivers, progress, problems - and the future». In S. Gossling, M. C. Hall, S. Page and D. Weaver (Eds.), Sustainable tourism futures: Perspectives on systems, restructuring and innovations (pp. 19-32). London: Routledge.

[57] LANE, B. (2016). «Implementing Sustainable Rural Tourism: Lessons from Rural Rail-based Slow Tourism». In E. Kastenholz, M.-J. Carneiro, C. Eusébio and E. Figueiredo (Eds.), Meeting Challenges for Rural Tourism through Co-Creation of Sustainable Tourist Experiences, 441-458. Cambridge, Cambridge Scholars Publishing. 
[58] LANE, B. (2018). «Will Sustainable Tourism Research be sustainable in the future? An opinion piece». Tourism Management Perspectives (in press. DOI: 10.1016/j. tmp.2017.12.001).

[59] LANE, B. and KASTENHOLZ, E. (2015). «Rural tourism: the evolution of practice and research approaches - towards a new generation concept?». Journal of Sustainable Tourism, 23 (8-9), 1133-1156.

[60] LANIER, J. (2017). Dawn of the New Everything: A Journey through Virtual Reality, London, Penguin Books.

[61] LUMSDON, L. (2000). «Transport and Tourism: Cycle Tourism - A Model for Sustainable Development?». Journal of Sustainable Tourism, 8 (5), 361-377.

[62] MAXIM, C. (2016). «Sustainable tourism implementation in urban areas: a case study of London». Journal of Sustainable Tourism, 24 (7), 971-989.

[63] MEADOWS, D. H.; MEADOWS, D. L.; RANDERS, J. and BEHRENS III, W. W. (1972). The Limits to Growth, New York, Universe Books, available on line at: http:// www.donellameadows.org/wp-content/userfiles/Limits-to-Growth-digital-scan-version. $p d f$.

[63] McCOOL, S. F. (2009). «Constructing partnerships for protected area tourism planning in an era of change and messiness». Journal of Sustainable Tourism, 17 (2), 133-148.

[64] McCOOL, S.; BUTLER, R.; BUCKLEY, R.; Weaver, D. and WHEELLER, B. (2013). «Is the Concept of Sustainability Utopian: Ideally Perfect but Impracticable?». Tourism Recreation Research, 38 (2), 213-242.

[65] McGeHEE, N. G.; KNOLlENBERG, W. and KOMOROWSKI, A. (2015). «The central role of leadership in rural tourism development: a theoretical framework and case studies». Journal of Sustainable Tourism, 23 (8-9), 1277-1297.

[66] MCKERCHER, B. (2005). «A case for ranking tourism journals». Tourism Management, 26, 649-651.

[67] McKERCHER, B. and CHEN, F. (2014). «Travel as a Life Priority?». Asia Pacific Journal of Tourism Research, 20 (7), 715-729.

[68] MCKERCHER, B.; LAW, R. and LAM, T. (2006). «Rating Tourism and Hospitality Journals». Tourism Management, 27, 1235-1252.

[69] McWHA, M.; FROST, W. and LAING, J. (2017). «Sustainable travel writing? Exploring the ethical dilemmas of twenty-first-century travel writers». Journal of Sustainable Tourism, 25 (10), 1401-1417.

[70] MEDINA, L. K. (2005). «Ecotourism and Certification: Confronting the Principles and Pragmatics of Socially Responsible Tourism». Journal of Sustainable Tourism, 13 (3), 281-295.

[71] MILLER, D.; MERRILEES, B. and COGHLAN, A. (2015). «Sustainable urban tourism: Understanding and developing visitor pro-environmental behaviours». Journal of Sustainable Tourism, 23 (1), 26-46.

[72] NUNKOO, R.; SMITH, S. L. J. and RAMKISSOON, H. (2013). «Residents' attitudes to tourism: a longitudinal study of 140 articles from 1984 to 2010». Journal of Sustainable Tourism, 21 (1), 5-25.

[73] OKAZAKI, E. (2008). «A Community-Based Tourism Model: Its Conception and Use». Journal of Sustainable Tourism, 16 (5), 511-529.

[74] PINE, B. J. and GILMORE, J. H. (1999). The Experience Economy. Boston, Harvard Business School Press. 
[75] SALAZAR, N. B. (2012). «Community-based cultural tourism: issues, threats and opportunities». Journal of Sustainable Tourism, 20 (1), 9-22.

[76] SCOTT, D. (2011). «Why sustainable tourism must address climate change». Journal of Sustainable Tourism, 19 (1), 17-34.

[77] SCUTTARI,A.; VOLGGER, M. and PECHLANER,H.(2016). «Transition management towards sustainable mobility in Alpine destinations: realities and realpolitik in Italy's South Tyrol region». Journal of Sustainable Tourism, 24 (3), 463-483.

[78] SHARPLEY, R. and Pearce, T. (2007). «Tourism, Marketing and Sustainable Development in the English National Parks: The Role of National Park Authorities». Journal of Sustainable Tourism, 15 (5), 557-573.

[79] SHULTIS, J. and WAY, P. A. (2006). «Changing Conceptions of Protected Areas and Conservation: Linking Conservation, Ecological Integrity and Tourism Management». Journal of Sustainable Tourism, 14 (3), 223-237.

[80] SIGALA, M. and GRETZEL, U. (2017). Advances in Social Media for Travel, Tourism and Hospitality: New Perspectives, Practice and Cases. Abingdon, Routledge.

[81] SLOCUM, S. L. (2017). «Operationalising both sustainability and neo-liberalism in protected areas: implications from the USA's National Park Service's evolving experiences and challenges». Journal of Sustainable Tourism, 25 (12), 18481864.

[82] STANFORD, D. and GUIVER, J. (2016). «Driving pro-environmental change in tourist destinations: encouraging sustainable travel in National Parks via partnership project creation and implementation». Journal of Sustainable Tourism, 24 (3), 484-505.

[83] SUNSTEIN, C. R. (2017). «Nudging and Choice Architecture: Ethical Considerations», published in the Yale Journal on Regulation and available at: http://www.law.harvard. edu/programs/olin_center/papers/pdf/Sunstein_809.pdf.

[84] THALER, R. and SUNSTEIN, C. (2008). Nudge. London, Penguin Books.

[85] TUBB, K. N. (2003). «An Evaluation of the Effectiveness of Interpretation within Dartmoor National Park in Reaching the Goals of Sustainable Tourism Development». Journal of Sustainable Tourism, 11 (6), 476-498.

[86] VON DER WEPPEN, J. and COCHRANE, J. (2012). «Social enterprises in tourism: an exploratory study of operational models and success factors». Journal of Sustainable Tourism, 20 (3), 497-511.

[87] WALL, G. and BADKE, C. (1994). «Tourism and climate change: An international perspective». Journal of Sustainable Tourism, 2 (4), 193-203.

[88] WEAVER, D. (2011). «Can sustainable tourism survive climate change?». Journal of Sustainable Tourism, 19 (1), 5-15.

[89] WHITELAW, P. A.; KING, B. E. M. and TOLKACH, D. (2014). «Protected areas, conservation and tourism - financing the sustainable dream». Journal of Sustainable Tourism, 22 (4), 584-603.

[90] WOLF, I. D.; AINSWORTH, G. B and CROWLEY, J. (2017). «Transformative travel as a sustainable market niche for protected areas: a new development, marketing and conservation model». Journal of Sustainable Tourism, 25 (11) 1650-1673.

[91] WORLD COMMISSION ON ENVIRONMENT AND DEVELOPMENT (WCED) (1987). The Brundtland Report. Oxford: Oxford University Press. 
[92] WRAY, M. (2011). «Adopting and implementing a transactive approach to sustainable tourism planning: translating theory into practice». Journal of Sustainable Tourism, 19 (4-5), 605-627.

[93] ZIELINSKI, S. and BOTERO, C. (2015). «Are eco-labels sustainable? Beach certification schemes in Latin America and the Caribbean». Journal of Sustainable Tourism, 23 (10), 1550-1572. 